\title{
Larval habitats, species composition and distribution of malaria vectors in regions with autochthonous and imported malaria in Roraima state, Brazil
}

Nathália Coelho Vargas de Almeida', Jaime Louzada², Maycon Sebastião Alberto Santos Neves ${ }^{3}$, Thiago M. Carvalho ${ }^{1}$, Júlio Castro-Alves ${ }^{4}$, Teresa Fernandes Silva-do-Nascimento ${ }^{3}$, Ananias A. Escalante ${ }^{5}$ and Joseli Oliveira-Ferreira ${ }^{1 *}$ (i)

\begin{abstract}
Background: Malaria control requires local action. Assessing the vector diversity and abundance provides information on the local malariogenic potential or risk of transmission. This study aimed to determine the Anopheles species composition, habitats, seasonal occurrence, and distribution in areas with autochthonous and imported malaria cases in Roraima State.

Methods: A longitudinal study was conducted from January 2017 to October 2018, sampling larvae and adult mosquitoes in three municipalities of Roraima State: Boa Vista, Pacaraima and São João da Baliza. These areas have different risks of malaria importation. Four to six mosquito larval habitats were selected for larval sampling at each municipality, along with two additional sites for adult mosquito collection. All larval habitats were surveyed every two months using a standardized larval sampling methodology and MosqTent for adult mosquitoes.

Results: A total of 544 Anopheles larvae and 1488 adult mosquitoes were collected from the three municipalities studied. Although the species abundance differed between municipalities, the larvae of Anopheles albitarsis s.l., Anopheles nuneztovari s.l. and Anopheles triannulatus s.l. were collected from all larval habitats studied while Anopheles darlingi were collected only from Boa Vista and São João da Baliza. Adults of 11 species of the genus Anopheles were collected, and the predominant species in Boa Vista was An. albitarsis (88.2\%) followed by An. darlingi (6.9\%), while in São João da Baliza, An. darlingi (85.6\%) was the most predominant species followed by An. albitarsis s.l. (9.2\%). In contrast, the most abundant species in Pacaraima was Anopheles braziliensis (62\%), followed by Anopheles peryassui (18\%). Overall, the majority of anophelines exhibited greater extradomicile than peridomicile-biting preference. Anopheles darlingi was the only species found indoors. Variability in biting times was observed among species and municipalities.
\end{abstract}

Conclusion: This study revealed the composition of anopheline species and habitats in Boa Vista, Pacaraima and São João da Baliza. The species sampled differed in their behaviour with only An. darlingi being found indoors. Anopheles darlingi appeared to be the most important vector in São João da Baliza, an area of autochthonous malaria, and

*Correspondence: lila@ioc.fiocruz.br

1 Laboratório de Imunoparasitologia, Instituto Oswaldo Cruz, Fundação Oswaldo Cruz, Rio de Janeiro, Brasil

Full list of author information is available at the end of the article

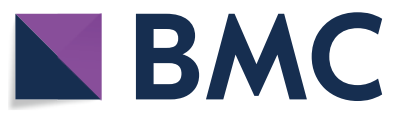

(c) The Author(s) 2021. Open Access This article is licensed under a Creative Commons Attribution 4.0 International License, which permits use, sharing, adaptation, distribution and reproduction in any medium or format, as long as you give appropriate credit to the original author(s) and the source, provide a link to the Creative Commons licence, and indicate if changes were made. The images or other third party material in this article are included in the article's Creative Commons licence, unless indicated otherwise in a credit line to the material. If material is not included in the article's Creative Commons licence and your intended use is not permitted by statutory regulation or exceeds the permitted use, you will need to obtain permission directly from the copyright holder. To view a copy of this licence, visit http://creativecommons.org/licenses/by/4.0/. The Creative Commons Public Domain Dedication waiver (http://creativeco mmons.org/publicdomain/zero/1.0/) applies to the data made available in this article, unless otherwise stated in a credit line to the data. 
An. albitarsis s.l. and An. braziliensis in areas of low transmission, although there were increasing reports of imported malaria. Understanding the diversity of vector species and their ecology is essential for designing effective vector control strategies for these municipalities.

Keywords: Malaria vectors, Larval habitats, Anopheles darlingi, Anopheles albitarsis s.l., Human biting rate, Imported malaria

\section{Background}

Malaria incidence in the Brazilian Amazon reduced from 333,461 cases in 2010 to 156,916 in 2019 [1]. Regardless of such regional progress, control interventions have not been successful in states sharing international borders, where malaria cases continue to increase [2-4]. Roraima is a Brazilian state in the extreme north of the country that shares international borders with Guyana and Venezuela. Since 2016, this region has been experiencing an unprecedented flow of migrants from Venezuela due to that country's economic, social and political crises [3, 5-7]. This uncontrolled migration translates into a larger number of imported cases $[2,8]$.

Data from the Ministry of Health, Epidemiological Surveillance Information System-malaria (SIVEP-malaria), shows that the number of cases reported in Roraima almost tripled from 8969 in 2016 to 23,369 in 2018. Of those, $34 \%$ were imported cases from other states in Brazil (3,630 cases) and other countries (5513 cases) [1, 2], particularly from Venezuela (4478 cases) and Guyana (610 cases) [1]. Two municipalities in Roraima, Boa Vista (the capital) and Pacaraima (bordering Venezuela), reported more than half of the imported malaria cases in Brazil across international borders between 2007 and 2018. Although these municipalities are considered areas of low transmission risk, the influx of migrants and cases makes them vulnerable to malaria outbreaks and epidemics $[2,8]$. The municipality of São João da Baliza (SJB) is located in the south of the state of Roraima, a region of tropical rainforest, endemic for malaria. In 2019, 634 cases were reported, of which 310 were acquired in the urban area of the municipality [1]. Furthermore, in Roraima state, Plasmodium falciparum infections were responsible for $9.8 \%$ of the autochthonous cases and $26 \%$ of the imported cases from other countries. Cross-border and authochtonous falciparum malaria threatens the Brazilian plan to eliminate this parasite from the country $[2,8]$, fuelling concern about importing parasites that are resistant to the drugs used to treat malaria in Brazil [912]. Therefore, characterizing the vector species involved in local transmission in these border municipalities and their larval habitats is considered a priority.

Anopheles darlingi, the most important malaria vector in the Brazilian Amazon is highly anthropophilic compared to other Amazonian anophelines, transmitting both $P$. falciparum and Plasmodium vivax [13-17]. Anopheles darlingi are found in a wide variety of larval habitats, such as streams, margin rivers, flooding areas, and dams surrounded by vegetation [14, 18-20]. Besides An. darlingi, other malaria vectors in the northern region include Anopheles albitarsis s.l., Anopheles nuneztovari s.l., Anopheles triannulatus s.l. and Anopheles braziliensis, which are mostly of local importance [4, 21-23].

In Roraima, previous studies conducted in Boa Vista reported that An. darlingi and An. albitarsis s.l. were the most relevant local vectors [24-27]. Anopheles darlingi had the highest infection rate, followed that of $A n$. albitarsis s.l., An. braziliensis and An. nuneztovari s.l. Anopheles albitarsis s.l. has been reported as the most common anopheline with the highest biting rate [22, 25-27]. Although An. darlingi and An. albitarsis s.l. are considered the primary malaria vectors in Boa Vista [24-27], An. albitarsis s.l. constitutes a complex of at least 10 species that are widely distributed in South America [25, 28-32]. However, only four species were incriminated as a vector of malaria parasites: Anopheles deaneorum [33] Anopheles janconnae (=An. albitarsis E)[26], Anopheles marajoara [34-36] and Anopheles albitarsis $\mathrm{F}[32,37]$. Anopheles albitarsis E $(=A n$. janconnae) has been reported as a malaria vector in Boa Vista. This species was abundant in the savannah biome, anthropophilic and showed biting behaviour predominantly in the early evening [26].

Considering the ongoing high levels of imported malaria in Roraima [1, 2], and the diverse ecological landscape in the state [38], this study aimed to identify anopheline larval habitats and mosquito species distribution and behaviour in areas with imported (Boa Vista and Pacaraima) and autochthonous malaria (São João da Baliza). The identification of potential larval habitats and the ecological conditions that determine the presence of Anopheles species competent to transmit Plasmodium is an important contribution for the control and elimination of malaria in Roraima.

This information will allow for the assessment of potential local malaria vectors in each municipality and may explain differences in transmission patterns. The long-term goal is to direct vector control measures as part of integrated policies to reduce the region's 
malariogenic potential and mitigate, if possible, the effect of imported malaria cases.

\section{Methods}

\section{Study areas}

The study was conducted in the municipalities of Boa Vista, Pacaraima and São João da Baliza, Roraima State (Fig. 1). These three municipalities were chosen because of their numbers of autochthonous and imported malaria cases, and their status in annual parasite incidence (IPA), a risk indicator for malaria transmission used by the Ministry of Health in Brazil. This indicator expresses the number of confirmed new infections, considering the likely place of infection, per year per 1,000 inhabitants. The urban areas of Boa Vista had a very low risk (IPA 0.4), while Pacaraima had a low risk (IPA 1.0) and São João da Baliza was considered a region with medium risk (IPA 37.8) for the year 2018. Boa Vista had an estimated population of 399,213 in 2019 and is located in the centre of the state $\left(02^{\circ} 49^{\prime} 12^{\prime \prime} \mathrm{N} ; 60^{\circ} 40^{\prime} 23^{\prime \prime} \mathrm{W}\right)$. It is $231 \mathrm{~km}$ from the main Venezuelan town in the country's malaria-endemic region (Santa Elena do Uairén), and it is $133 \mathrm{~km}$ from Guyana (Lethem). Its location allows easy access to the international borders and the state of Amazonas by highways. Indeed, Boa Vista predominated as the municipality with the most reported cases imported from neighbouring countries. In 2018, it registered 5,545 cases. Of these, 168 were autochthonous, 2115 were imported from Venezuela, and 533 from Guyana. Plasmodium falciparum infection imported from Venezuela (481 cases) and Guyana (97 cases) represented $80 \%$ of the $P$. falciparum registered in the city $(722$ cases) (1). Pacaraima is located in the north of the state $\left(04^{\circ} 25^{\prime} 51^{\prime \prime} \mathrm{N} ; 61^{\circ} 08^{\prime} 45^{\prime \prime} \mathrm{W}\right)$, in a mountainous region, above $1000 \mathrm{~m}$ altitude with an estimated population of 17,401 inhabitants, including 5838 indigenous peoples

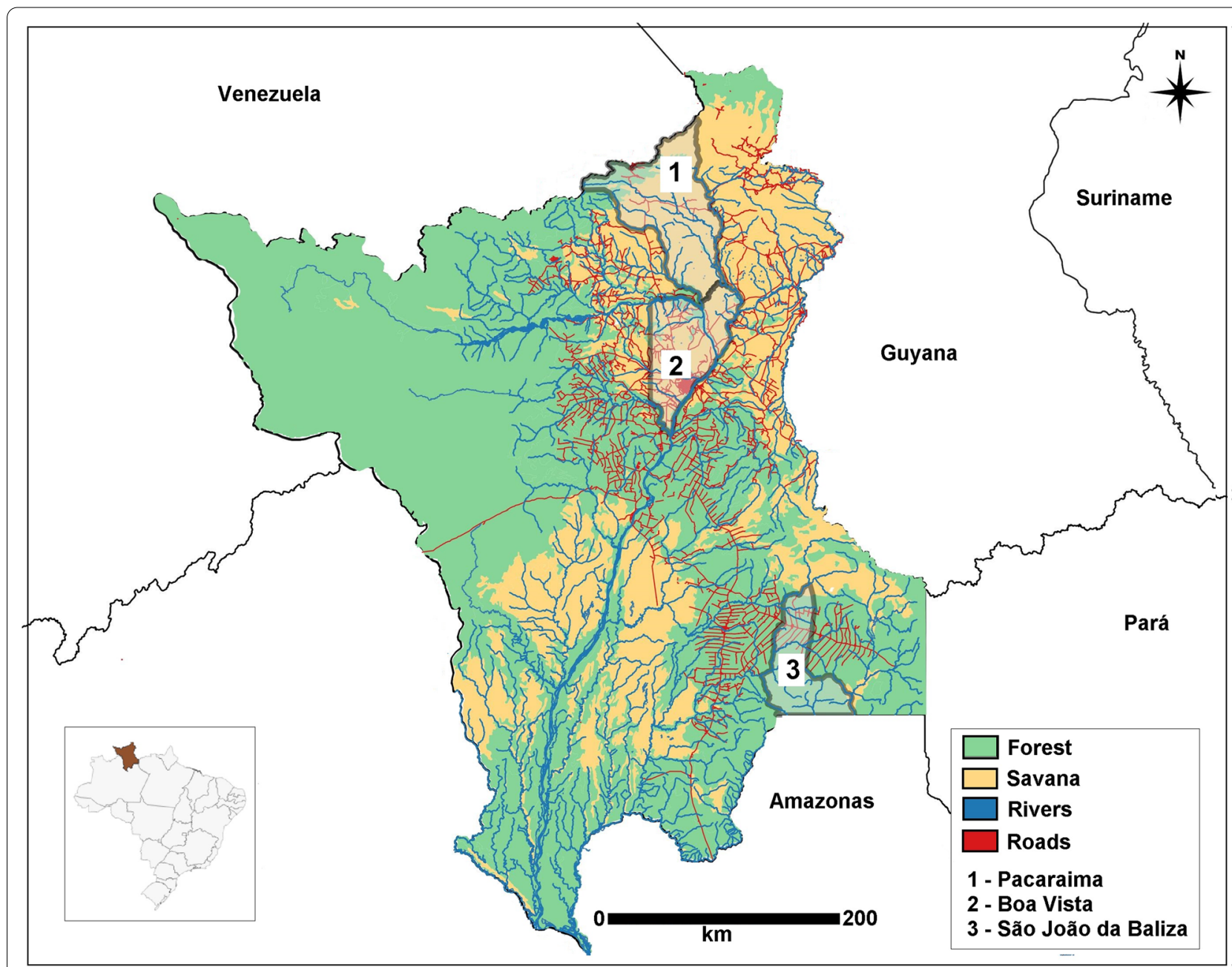

Fig. 1 Map of Roraima State with highlights on rivers, roads, vegetation, and locations of the municipalities of Pacaraima—1, Boa Vista—2 and São João da Baliza - 3 
of three ethnicities (Makuxi, Taurepang, Wapixana). This municipality presents an intense movement of people between Pacaraima and Santa Elena do Uairén. The imported malaria in this municipality is almost exclusively from Venezuela. Migration fluctuates according to the treatment offered in Santa Elena do Uairén, a border town with Pacaraima, or according to local political tensions; for example, in 2019, several conflicts in the region caused the closure of the border, with a decrease in the number of imported malaria cases from 2137 cases in 2018 to 268 cases in 2019. However, there has been an increase in autochthonous malaria cases in the indigenous communities (1577 cases) [1]. São João da Baliza is located in the south of the state $\left(0^{\circ} 57^{\prime} 03^{\prime \prime} \mathrm{N}\right.$; 59 $54^{\prime} 39^{\prime \prime}$ W), bordering Amazonas state, at a distance of $326 \mathrm{~km}$ from Boa Vista. The municipality is sparsely populated, with an estimated population of 8,201. In 2019, São João da Baliza reported 634 malaria cases; 461 were autochthonous, of which 310 were acquired in the urban area of the municipality, equivalent to $66.2 \%$, against 151 in the rural area. Imported malaria cases were low, with only two cases from Venezuela and French Guiana [1].
Study design and larval habitat collection larval and adult mosquitoes were collected every two months from January 2017 to October 2018. In each municipality, four to six mosquito larval habitats were selected and sampled for larvae and pupae, and two residences near the larval habitats were selected for adult mosquito collection (Fig. 2). The larval habitats were selected based on their proximity to houses where autochthonous cases occurred the year prior to the study and were positive for Anopheles spp. larvae in a preliminary survey conducted in October 2016. For each larval habitat, the following physicochemical and environmental parameters were determined: habitat type, size, water temperature, water $\mathrm{pH}$, degree of water turbidity, sun exposure, stream current, and vegetation. GPS estimated the distance from the larval habitat to the nearest house. Millimetric rods were used to measure the depth and size of the water bodies. The $\mathrm{pH}$ was determined using coloured dipsticks (MerckTM), and sun exposure and stream currents were visually estimated. Each larval habitat was identified by a number and georeferenced to determine its location (Fig. 2). In Boa Vista, the four larval habitats presented

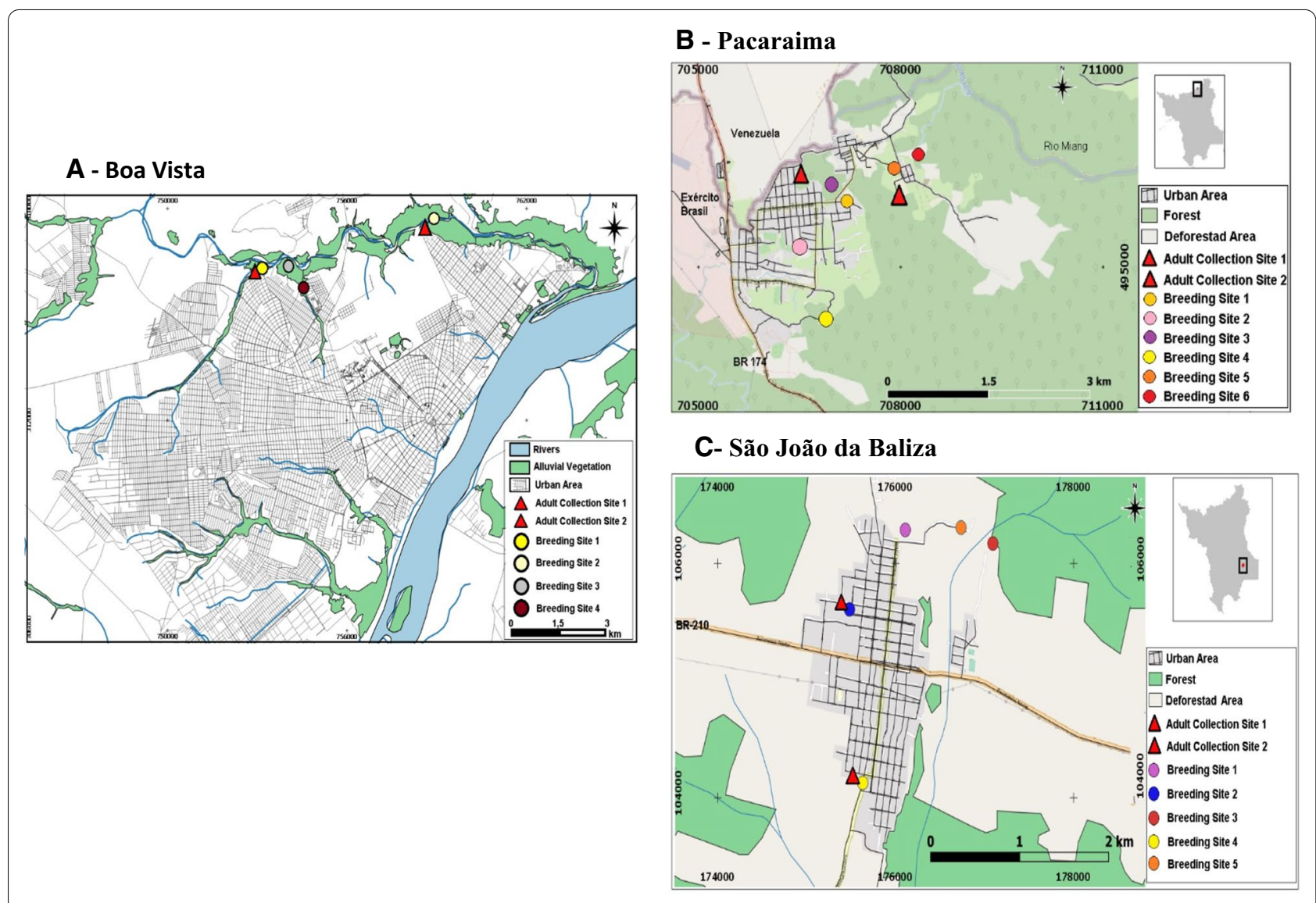

Fig. 2 Location of larval habitats, adult collection sites, and surrounding vegetation in Boa Vista (A), Pacaraima (B), and São João da Baliza (C) 
surrounding vegetation, and their geographical landscapes were characterized by the existence of savannah with and without gallery forests. In Pacaraima, $83 \%$ of the six larval habitats were located in the mountainous region of an ombrophilous forest. In São João da Baliza, $80 \%$ of the six larval habitats were surrounded by lowland tropical rainforest vegetation in a deforested area $[38,39]$.

\section{Larval surveys}

Larval surveys were performed on the same days as adult collections, from 07:00 to 13:00 $\mathrm{h}$ and in the afternoon, when necessary. Larval collection was performed using a 350-mL manual dipper (BioQuip, Ranch Dominguez, CA, USA) following a standardized larval sampling methodology recommendation of the Health Surveillance Secretariat of the Ministry of Health. The larvae and pupae collected were transferred to plastic tubes labelled with the larval habitat code, location, date, and collector's name. Larvae and pupae were either placed in $80 \%$ ethanol or reared in the laboratory to fourth instars or to adults, respectively, for identification using in Consoli and Lourenço-de-Oliveira dichotomous key for anopheline larvae [40].

\section{Adult survey}

Adult mosquitoes were collected in January, April, July and October of 2017 and 2018, comprising dry (November to April) and rainy (May to October) seasons. In each municipality, the collections were performed simultaneously at two sites, for three consecutive days at sunset from 18:00 to 21:00 and compared in the intradomicile, peridomicile and extradomicile areas. Sampling efforts throughout the studied period consisted of $480 \mathrm{~h}$ in each site: $144 \mathrm{~h}$ in the intradomicile (Nasci aspirator), $144 \mathrm{~h}$ in the peridomicile (MosqTent), and $192 \mathrm{~h}$ in the extradomicile ( $96 \mathrm{~h}$ with MosqTent and $96 \mathrm{~h}$ with Shannon).

In the intradomicile, mosquitoes were collected at rest on the internal walls and furniture, inside the residence, using a Nasci aspirator [41]. Peridomicile collections were performed approximately $15 \mathrm{~m}$ from the house using a protected human-baited mosquito trap (MosqTent) [42]. Extradomicile collections were carried $>15 \mathrm{~m}$ from the residence and the main larval habitat using MosqTent. When a horse was available, a baited Shannon trap was also used in the extradomicile concomitantly with the MosqTent collections. In order to assess the peak of haematophagy, collections were also performed in the intradomicile and extradomicile, for a 12-h period, from 18:00 to 06:00, in the months of April (transition from dry to rainy season) and October (transition from rainy to dry season) of 2017 and 2018. All data in relation to each collection (temperature, humidity, wind, rain) were recorded. Mosquitoes were collected using a manual
Castro aspirator, placed in paper cages and transported to the Laboratory of the State Entomology Centre in an appropriate Styrofoam box. The specimens were then euthanized with ethyl acetate. Individuals were transferred to plastic tubes (Eppendorf type) and kept in boxes containing hermetically sealed silica gels [40].

Species were morphologically identified using dichotomous keys for the Neotropical Anopheles species. Members of the An. albitarsis, An. nuneztovari and An. triannulatus complexes were not identified in this study; these species are referred to as sensu lato. Daily and monthly rainfall data were obtained from the National Water Agency (Agência Nacional de Águas, ANA).

\section{Geographical location of studied sites}

The geographic locations of larval habitats and adult collection sites were georeferenced in the Universal Transverse Mercator (UTM) coordinate system using the World Geodetic System 84 (WGS84). All geographic data were processed in the Landscape Metrics Laboratory of the Department of Geography of the Federal University of Roraima (UFRR), using satellite images and a cartographic basis of the municipalities. The data were processed in the QGIS 2.14.17 software to generate the maps such as those previously described [8].

\section{Statistical analysis}

Statistical analyses were performed using GraphPad InStat, version 3 (GraphPad Software, San Diego, CA, USA) and $\mathrm{R}$ version 4.0.5. Comparisons between mean temperature and $\mathrm{pH}$ were performed using the Wilcox test. To evaluate the association of environmental factors with the occurrence of species in larval habitats, univariate logistic models was used with species as the outcome. In particular, the environmental factors (habitat type, area, water turbidity, water current, water $\mathrm{pH}$, water temperature, house distance, sunlight exposure, and debris) were used as independent variables. The associations between species and environmental variables were presented as odds ratios (ORs) and their 95\% confidence intervals. Differences between the two non-reference categories were related to reference categories.

\section{Results}

\section{Characteristics of larval habitats}

Anopheles spp. larvae were found in all 15 permanent larval habitats in the studied municipalities: four sites in Boa Vista, six in Pacaraima, and five in São João da Baliza. Table 1 shows the main characteristics of each larval habitat and larvae of Anopheles spp. were found in all four types of water collection. Streams were widely distributed (66.6\%) in the study area, followed by dams (13.3\%), ponds (13.3\%) and lakes (6.6\%). In Boa Vista, 
Table 1 Characteristics of the larval habitats in Boa Vista, Pacaraima and São João da Baliza

\begin{tabular}{|c|c|c|c|c|c|c|c|}
\hline \multirow[t]{2}{*}{ Municipalities } & \multirow[t]{2}{*}{ Characteristics } & \multicolumn{6}{|l|}{ Larval Habitats } \\
\hline & & Site 1 & Site 2 & Site 3 & Site 4 & Site 5 & Site 6 \\
\hline \multirow[t]{10}{*}{ Boa Vista } & Habitat type & Stream & Lake & Stream & Stream & - & - \\
\hline & Area (sq m) & $>300$ & $>150 \leq 300$ & $>300$ & $>150 \leq 300$ & - & - \\
\hline & Water turbidity & Turbid & Transparent & Turbid & Transparent & - & - \\
\hline & Water current & Stagnant & Stagnant & Slow & Slow & - & - \\
\hline & $\begin{array}{l}\text { Water tempera- } \\
\text { ture }{ }^{\circ} \mathrm{C}(\mathrm{M} \pm \mathrm{SD})\end{array}$ & $23.2 \pm 10.5$ & $22.3 \pm 9.9$ & $28.7 \pm 14.9$ & $27.8 \pm 14.5$ & - & - \\
\hline & $\begin{array}{l}\text { Water pH } \\
(\mathrm{M} \pm \mathrm{SD})\end{array}$ & $5.4 \pm 2.4$ & $4.7 \pm 2.4$ & $2.9 \pm 3.1$ & $3.4 \pm 2.9$ & - & - \\
\hline & $\begin{array}{l}\text { Distance from } \\
\text { houses }(m)\end{array}$ & $>15$ & $>15$ & $>15$ & $\leq 8$ & - & - \\
\hline & $\begin{array}{l}\text { Sunlight expo- } \\
\text { sure }\end{array}$ & Partly shaded & Partly shaded & Partly shaded & Shaded & - & - \\
\hline & Debris & $\begin{array}{l}\text { Trunk/Roots/ } \\
\text { Leaves }\end{array}$ & $\begin{array}{l}\text { Trunk/Roots/ } \\
\text { Leaves }\end{array}$ & $\begin{array}{l}\text { Trunk/Roots/ } \\
\text { Leaves }\end{array}$ & $\begin{array}{l}\text { Trunk/Roots/ } \\
\text { Leaves }\end{array}$ & - & - \\
\hline & Vegetation & $\begin{array}{l}\text { Emerging/Mar- } \\
\text { ginal }\end{array}$ & $\begin{array}{l}\text { Emerging/Mar- } \\
\text { ginal } \\
\text { Floating/Under- } \\
\text { water }\end{array}$ & $\begin{array}{l}\text { Emerging/Float- } \\
\text { ing } \\
\text { Marginal }\end{array}$ & $\begin{array}{l}\text { Floating/Mar- } \\
\text { ginal }\end{array}$ & - & - \\
\hline \multirow[t]{10}{*}{ Pacaraima } & Habitat type & Pond & Stream & Stream & Stream & Fishpond & Stream \\
\hline & Area (sq m) & $\leq 150$ & $>150 \leq 300$ & $>150 \leq 300$ & $\leq 150$ & $>300$ & $>150 \leq 300$ \\
\hline & Water turbidity & Turbid & Transparent & Transparent & Transparent & Turbid & Turbid \\
\hline & Current water & Slow & Moderate & Slow & Moderate & Stagnant & Slow \\
\hline & $\begin{array}{l}\text { Water tempera- } \\
\text { ture }{ }^{\circ} \mathrm{C}(\mathrm{M} \pm \mathrm{SD})\end{array}$ & $20.9 \pm 8.5$ & $20.1 \pm 8.1$ & $19.2 \pm 8.5$ & $19.5 \pm 8.6$ & $22 \pm 9.7$ & $21.2 \pm 9.4$ \\
\hline & $\begin{array}{l}\text { Water pH } \\
(\mathrm{M} \pm \mathrm{SD})\end{array}$ & $5.5 \pm 1$ & $6.3 \pm 2.8$ & $6.9 \pm 0.7$ & $5.4 \pm 2.4$ & $7 \pm 0.8$ & $5.4 \pm 2.2$ \\
\hline & $\begin{array}{l}\text { Distance from } \\
\text { houses }(m)\end{array}$ & $\leq 8$ & $>8 \leq 15$ & $\leq 8$ & $>8 \leq 15$ & $>15$ & $>15$ \\
\hline & $\begin{array}{l}\text { Sunlight expo- } \\
\text { sure }\end{array}$ & Partly shaded & Shaded & Shaded & Shaded & Sunny & Partly shaded \\
\hline & Debris & $\begin{array}{l}\text { Trunk/Roots/ } \\
\text { Leaves }\end{array}$ & $\begin{array}{l}\text { Trunk/Roots/ } \\
\text { Leaves }\end{array}$ & $\begin{array}{l}\text { Trunk/Roots/ } \\
\text { Leaves }\end{array}$ & $\begin{array}{l}\text { Trunk/Roots/ } \\
\text { Leaves }\end{array}$ & Nothing & $\begin{array}{l}\text { Trunk/Roots/ } \\
\text { Leaves/Fruits }\end{array}$ \\
\hline & Vegetation & $\begin{array}{l}\text { Floating/Under- } \\
\text { water } \\
\text { Marginal }\end{array}$ & $\begin{array}{l}\text { Emerging/Float- } \\
\text { ing } \\
\text { Marginal }\end{array}$ & $\begin{array}{l}\text { Emerging/Mar- } \\
\text { ginal }\end{array}$ & $\begin{array}{l}\text { Emerging/Mar- } \\
\text { ginal }\end{array}$ & Underwater & $\begin{array}{l}\text { Emerging/Mar- } \\
\text { ginal Underwater }\end{array}$ \\
\hline \multirow[t]{10}{*}{ S.J. Baliza } & Habitat type & Dam & Stream & Stream & Stream & Dam & - \\
\hline & Area (sq m) & $>300$ & $\leq 150$ & $>300$ & $>150 \leq 300$ & $\leq 150$ & - \\
\hline & Water turbidity & Turbid & Turbid & Transparent & Turbid & Turbid & - \\
\hline & Current water & Slow & Slow & Slow & Moderate & Stagnant & - \\
\hline & $\begin{array}{l}\text { Water tempera- } \\
\text { ture }{ }^{\circ} \mathrm{C}(\mathrm{M} \pm \mathrm{SD})\end{array}$ & $27 \pm 2.3$ & $25.8 \pm 1.1$ & $25.1 \pm 0.4$ & $27.5 \pm 1.7$ & $26.6 \pm 2.3$ & - \\
\hline & $\begin{array}{l}\text { Water pH } \\
(\mathrm{M} \pm \mathrm{SD})\end{array}$ & $5.5 \pm 2.3$ & $5.5 \pm 2.3$ & $6.5 \pm 0.8$ & $5.5 \pm 2.3$ & $5.5 \pm 3.5$ & - \\
\hline & $\begin{array}{l}\text { Distance from } \\
\text { houses }(m)\end{array}$ & $>8 \leq 15$ & $\leq 8$ & $\leq 8$ & $>8 \leq 15$ & $>15$ & - \\
\hline & $\begin{array}{l}\text { Sunlight expo- } \\
\text { sure }\end{array}$ & Partly shaded & Partly shaded & Partly shaded & Shaded & Sunny & - \\
\hline & Debris & $\begin{array}{l}\text { Trunk/Roots/ } \\
\text { Leaves }\end{array}$ & $\begin{array}{l}\text { Trunk/Roots/ } \\
\text { Leaves }\end{array}$ & $\begin{array}{l}\text { Trunk/Roots/ } \\
\text { Leaves }\end{array}$ & $\begin{array}{l}\text { Trunk/Roots/ } \\
\text { Leaves }\end{array}$ & Nothing & - \\
\hline & Vegetation & $\begin{array}{l}\text { Emerging/Mar- } \\
\text { ginal }\end{array}$ & $\begin{array}{l}\text { Emerging/Mar- } \\
\text { ginal }\end{array}$ & $\begin{array}{l}\text { Emerging/Mar- } \\
\text { ginal }\end{array}$ & $\begin{array}{l}\text { Emerging/ } \\
\text { Underwater } \\
\text { Marginal }\end{array}$ & Underwater & - \\
\hline
\end{tabular}


the types of water collections were streams and lakes; in Pacaraima, streams, ponds and fishponds, and São João da Baliza, streams and dams. Furthermore, 26.7\% of the habitats had a surface area of $<150 \mathrm{sq} \mathrm{m}$, while $40 \%$ were $>150<300 \mathrm{sq} \mathrm{m}$ and $33.3 \%$ had a surface area greater than $300 \mathrm{sq} \mathrm{m}$. The majority of the larval habitats in Boa Vista were located at a distance $>15 \mathrm{~m}$ from houses, while in Pacaraima and São João da Baliza, they were $<15 \mathrm{~m}$. Anopheles spp. larvae were found in both transparent $(60 \%)$ and turbid $(40 \%)$ water habitats. In most larval habitats, the water current was slow-moving (53.3\%) or stagnant $(26.7 \%)$, and the temperature and $\mathrm{pH}$ were distinct in the habitats sampled. In the municipality of Pacaraima, the larval habitats presented a lower water temperature $(20.48 \pm 1.0)$ than in Boa Vista (25.5 \pm 3.2 ; $\mathrm{p}<0.0001)$ and São João da Baliza $(26.4 \pm 0.95 ; \mathrm{p}<0.01)$, and a higher $\mathrm{pH}(6.0 \pm 0.75)$ when compared to Boa Vista $(4.1 \pm 1.15 ; \mathrm{p}<0.01)$. This study further observed that 53.3 and $33.3 \%$ of the habitats were partially shaded and shaded, respectively. Half of the larval habitats in Pacaraima were shaded, while in Boa Vista and São João da Baliza the majority were partially shaded. Only two larval habitats were in full sun, one of which was in Pacaraima and the other in São João da Baliza. Marginal vegetation was present in all larval habitats, while emerging vegetation was present in $73.3 \%$, underwater in $40 \%$, and floating vegetation in $33.3 \%$. Debris such as tree trunks, leaves and roots, were found in all water bodies except in one fishpond in São João da Baliza.

\section{Identification of immature forms of anophelines}

A total of 544 Anopheles spp. specimens were obtained from 15 larval habitats, and the relative abundance of each larval species encountered is presented in Table 2. A total of 12 species were identified from 209 late-instar larvae (third and fourth stages). However, 335 Anopheles spp larvae were not identified at the species level and considered for statistical analysis, mainly because they were early instar larvae (first and second stages) or were damaged. Collections of the immature forms showed that An. albitarsis s.l., An. nuneztovari s.l., An. triannulatus s.l., and Anopheles peryassui were collected from larval habitats from all municipalities while $A n$. darlingi, Anopheles matogrossensis and Anopheles oswaldoi s.l. were only observed in Boa Vista and São João da Baliza. Anopheles evansae was present in Boa Vista and Pacaraima, Anopheles mediopunctatus and Anopheles argyritarsis only in Pacaraima and Chagasia bonneae and Anopheles strodei were only found in São João da Baliza.

In Boa Vista, 99 larvae of eight species were collected mainly from two larval habitats; An. darlingi (44.4\%) was the most abundant species, followed by An. nuneztovari s.l. (26.9\%) and An. albitarsis s.l. (9.5\%). During the study period, in the larval habitats 3 and 4, larvae of $A n$. nuneztovari s.l. were collected, while at site 4, only a few second stage Anopheles larvae were collected. The municipality of São João da Baliza presented the highest number of larvae collected (264) of nine species and $A n$. darlingi was present in all five larval habitats, whereas in Boa Vista, this species was present in only two larval habitats. In São João da Baliza, An. nuneztovari s.l. (18.6\%) and An. albitarsis s.l. (8.8\%) were also prevalent. Pacaraima showed a total of 148 larvae of seven species collected, and An. triannulatus s.l. (33.3\%) was the most abundant species, followed by An. albitarsis s.l. (24.2\%) and An. argyritarsis (18.1\%). All An. triannulatus s.l. were collected from a single larval habitat (5) in a fishpond. Immature forms of $A n$. darlingi were present in streams, lakes, and dams with transparent or turbid water, in partially shaded or sunny habitats. However, in these larval habitats, the water had a lower $\mathrm{pH}$ and higher water temperature.

\section{Association between anopheline larvae and environmental factors}

The univariate logistic models for the four most frequent Anopheles species are summarized in Table 3. Anopheles darlingi was more likely to occur in the stream larval habitat $(\mathrm{OR}=6.85, \mathrm{p}<0.01)$ compared with An. nuneztovari s.l., which was found in a dam $(\mathrm{OR}=0.16, \mathrm{p}<0.01)$. Anopheles triannulatus s.l. had a preference for fishponds (OR $=40.7, \mathrm{p}<0.01)$. Larvae of An. albitarsis s.l. and An. darlingi had a higher chance of being captured in larval habitats with 150-300 sq $\mathrm{m}$ of surface area than those larger than $300 \mathrm{sq} \mathrm{m}(\mathrm{OR}=3.83, \mathrm{p}<0.05$, and $\mathrm{OR}=2.27$, $\mathrm{p}<0.05$, respectively. Anopheles darlingi was also less abundant in stagnant water $(\mathrm{OR}=0.08, \mathrm{p}<0.01)$ and slow currents $(\mathrm{OR}=0.12, \mathrm{p}<0.01)$ than in moderate water currents. The logistic models also showed a higher chance of An. triannulatus s.l. to be found in larval habitats $>300$ sq $\mathrm{m}(\mathrm{OR}=0.13, \mathrm{p}<0.01)$ than those $<150-300$ sq $\mathrm{m}(\mathrm{OR}=0.29, \mathrm{p}<0.05)$. Anopheles albitarsis s.l. had a greater preference for aquatic habitats with transparent waters over turbid water $(\mathrm{OR}=0.24, \mathrm{p}<0.01)$. In contrast, An. darlingi and An. nuneztovari s.l. occurred in aquatic habitats with both transparent and turbid water. Habitats exposed to the sun were related to the occurrence of $A n$. albitarsis s.l. $(\mathrm{OR}=2.93, \mathrm{p}<0.05)$, and $A n$. triannulatus s.l. $(\mathrm{OR}=15.67, \mathrm{p}<0.01)$ in comparison to those partially shaded, while $A n$. darlingi showed a preference for partially shaded over full sun habitats $(\mathrm{OR}=0.1, \mathrm{p}<0.01)$. Anopheles darlingi was more frequently observed in the presence of roots, tree trunks and leaves $(\mathrm{OR}=12.58, \mathrm{p}<0.01)$ than in the absence of 
debris, while An. triannulatus s.l. was less likely to occur in habitats with debris $(\mathrm{OR}=0.08, \mathrm{p}<0.01)$.

\section{Species distribution of adult anopheline}

A total of 1,488 female Anopheles from 11 species were collected from all three municipalities (Table 4). Nine species were identified in Boa Vista and An. albitarsis s.l. (88.4\%) was the predominant species, followed by $A n$. darlingi (6.9\%) and An. peryassui (3\%). Among the seven species collected from São João da Baliza, An. darlingi (85.6\%) was the most predominant species, followed by An. albitarsis s.l. (9.3\%), and An. nuneztovari s.l. (3.9\%). Pacaraima showed lower vector density than the municipalities of Boa Vista, and of the six species identified, the most abundant was An. braziliensis (64.6\%), followed by An. peryassui (18.7\%) and An. albitarsis s.l. (8.3\%). In all three municipalities An. albitarsis s.l., An. darlingi and An. nuneztovari s.l. were present, whereas An. matogrossensis and An. evansae were observed only in Boa Vista and An. triannulatus s.l. only in São João da Baliza. Overall, the majority of anophelines exhibited greater extradomicile than peridomicile biting preferences. Anopheles darling $i$ was the only species found in the intradomicile. In Boa Vista and São João da Baliza An. darlingi and $A n$. albitarsis s.l. were more abundant in the extradomicile than in the peridomicile. However, in Pacaraima and Boa Vista An. darlingi and An. albitarsis s.l. were also collected in the Shannon trap. In Pacaraima, An. braziliensis was captured in the peridomicile (33.8\%), and in the extradomicile by MosqTent (29\%) and by the Shannon trap collection (37.1\%).

\section{Seasonal variation of Anopheles in each municipality}

The longitudinal study showed variation in the abundance of Anopheles species according to the period studied (Fig. 3). The collection each month represents the mean number of Anopheles captured in that month per collector per hour (4 $\mathrm{h}$ of capture for three consecutive days) for every two months in each locality.

The rainy season in the state of Roraima occurs between April and September. Even so, in Boa Vista this was the period with the greatest abundance of Anopheles. In Pacaraima and São João da Baliza these species were more frequent in the driest months. In Boa Vista (Fig. 3A) An. albitarsis s.l. had the highest density during the studied months, with the greatest frequency observed in April in the dry season. The month of July for both years (2017 and 2018) had the greatest rainfall, and a large number of An. albitarsis s.l. were captured in 2018. Anopheles darlingi was not abundant during the study months but showed a population increase in October at the end of the rainy season.

In Pacaraima (Fig. 3B), An. braziliensis was the most abundant species collected in higher numbers in October, two months after the high record for rain precipitation, while An. albitarsis s.l. were collected in fewer numbers during most of the months of collection. In São João da Baliza (Fig. 3C), An. darlingi was predominant throughout the year, and this species was more abundant in October, whereas An. albitarsis s.l. was also collected in every month but in lower numbers.

The dispersion of Anopheles by average rainfall intensity and temperature showed that An. darlingi was predominant when the temperature was above $24^{\circ} \mathrm{C}$ and in the periods with less rainfall, while An. albitarsis s.l. prevailed during periods of rain, with temperatures above $23^{\circ} \mathrm{C}$. Anopheles braziliensis was collected at lower temperatures $\left(18^{\circ} \mathrm{C}\right.$ and $\left.25^{\circ} \mathrm{C}\right)$ during both the dry and rainy periods. Anopheles peryassui was the vector that was intermediate to all these periods and was not captured in the extremely dry period (Additional file 1: Fig. S1).

\section{Biting activity and human bite rate}

Four 12-h collections were conducted in each municipality simultaneously in the intradomicile and peridomicile to analyse biting activity. Although all collections were performed in both environments, no samples were collected in the intradomicile. Figure 4 shows the frequency (\%) of the two more frequent Anopheles species in each locality occurring in the peridomicile at hourly intervals. Variability in biting times was observed among species and municipalities. In Boa Vista, An. albitarsis s.l., the most abundant species, presented biting activity at dusk and throughout the night, with most of the activity between 02:00 and 04:00. Anopheles darlingi presented biting activity at 20:00-21:00 and throughout the night, but in lower numbers with the majority between 20:00 and 21:00 and 02:00-3:00, with only one specimen of $A n$. peryassui captured at 20:00-21:00. In Pacaraima, the most frequently occurring species was An. braziliensis, with a significant peak at 19:00-20:00. Anopheles argyritarsis was caught between 18:00 and 19:00 and 19:00-20:00, and An. peryassui at 18:00-19:00. In the municipality of São João da Baliza, An. darlingi exhibited a pronounced crepuscular biting activity with an early peak at 21:0022:00. However, they were also collected throughout the night until 06:00. Anopheles nuneztovari was the second-most common species, occurring from 20:00 to $21: 00,21: 00$ to $22: 00$ and from $23: 00$ to $00: 00$, while An. albitarsis s.l. occurred in higher numbers at 05:00 to $06: 00$. 
Table 2 The relative abundance of each larvae species collected at larval habitats in the municipalities of Boa Vista, Pacaraima and São João da Baliza

\begin{tabular}{|c|c|c|c|c|c|c|c|c|}
\hline \multirow[t]{3}{*}{ Municipalities } & \multirow[t]{3}{*}{ Species } & \multicolumn{6}{|c|}{ Larval habitats } & \multirow{3}{*}{$\begin{array}{l}\text { Total } \\
\text { N (\%) }\end{array}$} \\
\hline & & Site 1 & Site 2 & Site 3 & Site 4 & Site 5 & Site 6 & \\
\hline & & N (\%) & N (\%) & $\mathrm{N}(\%)$ & N (\%) & $\mathrm{N}(\%)$ & N (\%) & \\
\hline & & Stream & Lake & Stream & Stream & - & - & \\
\hline \multirow[t]{11}{*}{ Boa Vista } & An. darlingi & $13(65.0)$ & $15(38.5)$ & 0 & 0 & - & - & $28(44.4)$ \\
\hline & An. albitarsis s.l. & 0 & $6(15.4)$ & 0 & 0 & - & - & $6(9.5)$ \\
\hline & An. nuneztovari s.l. & $2(10.0)$ & $11(28.2)$ & $4(100)$ & 0 & - & - & $17(27.0)$ \\
\hline & An. mattogrossensis & $4(20)$ & 0 & 0 & 0 & - & - & $4(6.3)$ \\
\hline & An. triannulatus s.l. & $1(5.0)$ & 0 & 0 & 0 & - & - & $1(1.6)$ \\
\hline & An. evansae & 0 & $5(12.8)$ & 0 & 0 & - & - & $5(7.9)$ \\
\hline & An. peryassui & 0 & $1(2.6)$ & 0 & 0 & - & - & $1(1.6)$ \\
\hline & An. oswaldois.l. & 0 & $1(2.6)$ & 0 & 0 & - & - & $1(1.6)$ \\
\hline & Total & $20(31.7)$ & $39(61.9)$ & $4(6.4)$ & 0 & - & - & $63(100)$ \\
\hline & *Anopheles spp. & 18 & 13 & 3 & 2 & - & - & 36 \\
\hline & & Pond & Stream & Stream & Stream & Fishpond & Stream & \\
\hline \multirow[t]{10}{*}{ Pacaraima } & An. albitarsis s.l. & 0 & 0 & $6(100)$ & 0 & $2(13.33)$ & 0 & $8(24.2)$ \\
\hline & An. nuneztovari s.l. & $1(100)$ & 0 & 0 & 0 & 0 & 0 & $1(3.0)$ \\
\hline & An. triannulatus s.l. & 0 & 0 & 0 & 0 & $11(73.33)$ & 0 & $11(33.3)$ \\
\hline & An. evansae & 0 & 0 & 0 & 0 & $1(6.66)$ & 0 & $1(3.0)$ \\
\hline & An. peryassui & 0 & 0 & 0 & $4(100)$ & $1(6.66)$ & 0 & $5(15.1)$ \\
\hline & An. mediopunctatus & 0 & 0 & 0 & 0 & 0 & $1(100)$ & $1(3.0)$ \\
\hline & An. argyritarsis & 0 & $6(100)$ & 0 & 0 & 0 & 0 & $6(18.2)$ \\
\hline & Total & $1(3.0)$ & $6(18.2)$ & $6(18.2)$ & $4(12.1)$ & $15(45.4)$ & $1(3.0)$ & 33 \\
\hline & *Anopheles spp. & 4 & 41 & 32 & 8 & 58 & 5 & 148 \\
\hline & & Dam & Stream & Stream & Stream & Dam & - & \\
\hline \multirow[t]{11}{*}{ S.J. Baliza } & An. darlingi & $8(38.0)$ & $16(66.7)$ & $3(37.5)$ & $31(86.1)$ & $4(16.7)$ & - & $62(62.9)$ \\
\hline & An. albitarsis s.l. & $1(4.8)$ & $2(8.3)$ & 0 & $1(2.8)$ & $6(25.0)$ & - & $10(8.8)$ \\
\hline & An. nuneztovari s.l. & $9(42.8)$ & $3(12.5)$ & 0 & 0 & $9(37.5)$ & - & $21(18.6)$ \\
\hline & An. mattogrossensis & 0 & 0 & $1(12.5)$ & 0 & 0 & - & $1(0.9)$ \\
\hline & An. triannulatus s.l. & $2(9.5)$ & $1(4.2)$ & 0 & $3(8.3)$ & $3(12.5)$ & - & $9(8.0)$ \\
\hline & An. peryassui & 0 & 0 & $1(12.5)$ & 0 & 0 & - & $1(0.9)$ \\
\hline & Chagasiabonneae & 0 & 0 & $3(37.5)$ & 0 & 0 & - & $3(2.6)$ \\
\hline & An. oswaldois.l. & $1(4.8)$ & $2(8.3)$ & 0 & $1(2.8)$ & $1(4.2)$ & - & $5(4.4)$ \\
\hline & An. strodei & 0 & 0 & 0 & 0 & $1(4.2)$ & - & $1(0.9)$ \\
\hline & Total & $21(18.6)$ & $24(21.2)$ & $8(7.1)$ & $36(31.8)$ & $24(21.2)$ & - & 113 \\
\hline & *Anopheles spp. & 13 & 11 & 5 & 17 & 105 & - & 151 \\
\hline
\end{tabular}

- Not done

${ }^{*}$ Anopheles spp.: Anopheles that were not identified at the species level, mainly because they were early instar larvae (first and second stages) or were damaged

The human biting rate (HBR) was estimated for the most common species collected in each municipality using the following calculation: the total number of anophelines captured during the 4-h collection (16:00 to 21:00) divided by the total number of collection days and the number of collectors. The data are presented in Table 5. Among all species collected in Boa Vista, An. albitarsis s.l. showed the highest rate in the extradomicile (10.8 bites per night) followed by 3.8 in the peridomicile.
The presence of $A n$. darlingi predominates with a low HBR in the peridomicile ( 0.3 bites) and in the extradomicile (0.8 bites). In Pacaraima, HBR was low in both the peridomicile (0.26) and extradomicile (0.22) for An. braziliensis. In the municipality of São João da Baliza, $A n$. darlingi presented higher HBR in the peridomicile (1.07) and in the extradomicile (1.64) than in Boa Vista while An. albitarsis s.l. had a very low HBR. Moreover, São João da Baliza was the only municipality where An. darlingi 
Table 3 Univariate model to estimate OR (Cl 95\%) for the association of environmental factors in larval habitats with the occurrence of Anopheles species

\begin{tabular}{|c|c|c|c|c|c|}
\hline \multirow[t]{2}{*}{ Variables } & & \multicolumn{4}{|l|}{ Anopheles species } \\
\hline & & An. albitarsis s.l. & An. darlingi & An. nuneztovari s.l. & $\begin{array}{l}\text { An. triannulatus } \\
\text { s.l. }\end{array}$ \\
\hline \multirow[t]{5}{*}{ Habitat type } & Dam & Ref & Ref & Ref & Ref \\
\hline & Fishpond & $0.91(0.12 ; 4.46)$ & $0(0 ; 136.02)$ & - & $40.7(8.21 ; 322.05)^{* *}$ \\
\hline & Lake & $1.15(0.34 ; 3.88)$ & $2.21(0.85 ; 5.89)$ & $0.7(0.26 ; 1.8)$ & - \\
\hline & Pond & - & - & - & - \\
\hline & Stream & $0.58(0.2 ; 1.75)$ & $6.85(3.08 ; 16.08)^{* *}$ & $0.16(0.06 ; 0.38)^{* *}$ & $0.46(0.12 ; 1.73)$ \\
\hline \multirow[t]{3}{*}{ Area (Sq m) } & $>300 \mathrm{~m}$ & Ref & Ref & Ref & Ref \\
\hline & $150-300 \mathrm{~m}$ & $3.83(1.16 ; 17.35)^{*}$ & $2.27(1.12 ; 4.67)^{*}$ & $0.48(0.2 ; 1.15)$ & $0.13(0.03 ; 0.42)^{* *}$ \\
\hline & $<150 m$ & $3.82(1.03 ; 18.32)$ & $1.07(0.48 ; 2.36)$ & $1.11(0.46 ; 2.67)$ & $0.29(0.08 ; 0.89)^{*}$ \\
\hline \multirow[t]{2}{*}{ Water turbidity } & Transparent & Ref & Ref & Ref & Ref \\
\hline & Turbid & $0.24(0.1 ; 0.59)^{* *}$ & $1.51(0.75 ; 3.08)$ & $0.73(0.33 ; 1.68)$ & - \\
\hline \multirow[t]{3}{*}{ Water current } & Moderate & Ref & Ref & Ref & Ref \\
\hline & Stagnant & $6.9(1.3 ; 127.59)$ & $0.08(0.02 ; 0.23)^{* *}$ & - & $2.35(0.71 ; 10.67)$ \\
\hline & Slow & $6.51(1.14 ; 122.92)$ & $0.12(0.03 ; 0.35)^{* *}$ & - & $0.6(0.11 ; 3.43)$ \\
\hline \multirow[t]{3}{*}{ Distance houses } & $>15 \mathrm{~m}$ & Ref & Ref & Ref & Ref \\
\hline & $15-8 \mathrm{~m}$ & $0.2(0.03 ; 0.74)^{*}$ & $4.19(2.06 ; 8.85)^{* *}$ & $0.46(0.19 ; 1.04)$ & $0.48(0.15 ; 1.33)$ \\
\hline & $<8 \mathrm{~m}$ & $1.74(0.63 ; 4.59)$ & $2.51(1.11 ; 5.86)^{*}$ & $0.34(0.09 ; 0.96)$ & $0.15(0.01 ; 0.82)$ \\
\hline \multirow[t]{3}{*}{ Sunlight exposure } & Partly shaded & Ref & Ref & Ref & Ref \\
\hline & Shaded & $2.04(0.68 ; 5.9)$ & $2.42(1.1 ; 5.71)^{*}$ & - & $1.86(0.35 ; 8.8)$ \\
\hline & Full sun & $2.93(1.01 ; 8.41)^{*}$ & $0.1(0.03 ; 0.28)^{* *}$ & $0.78(0.32 ; 1.83)$ & $15.67(5.06 ; 59.78)^{* *}$ \\
\hline \multirow[t]{2}{*}{ Debris } & Nothing & Ref & Ref & Ref & Ref \\
\hline & Trunk/Roots/Leaves & $0.44(0.17 ; 1.18)$ & $12.58(4.66 ; 44.06)^{* *}$ & $0.8(0.35 ; 1.96)$ & $0.08(0.03 ; 0.21)^{* *}$ \\
\hline
\end{tabular}

Statistically significant $\left({ }^{*} p<0.05\right.$; and ${ }^{* *} p<0.01 ;-$ small sample size

was collected in the intradomicile (three specimens at 19:00-20:00 and one at 20:00-21:00).

\section{Discussion}

Malariogenic potential measures the risk of transmission in a given area. It is critical for determining strategies to eliminate and prevent the re-establishment of malaria transmission [43], particularly in areas where the potential of imported malaria is high. As part of an integrated strategy for control and elimination, interventions should be deployed regionally based on detailed knowledge of local vector habitats and distribution. Here, during two years, the larval habitat and adults were sampled to determine the Anopheles species composition, seasonal occurrence and distribution of vectors in areas of autochthonous (São João da Baliza) and with high numbers of imported (Boa Vista and Pacaraima) malaria in Roraima. Differences in mosquito distribution and richness among sites may be the most important factors for identifying local variation in malaria transmission. Roraima presents a diverse ecological landscape and malaria transmission in Boa Vista, which is mainly savannah, which differs from that of the Yanomami Indian reserves in the northwestern mountains, which is a region with dense rainforest [24-26, 38, 44].

In all municipalities, the most-encountered larval habitats were streams. Anopheles darlingi was the most abundant larval species in São Joao da Baliza and Boa Vista. However, in São João da Baliza, where vegetation consists of a lowland tropical rainforest in a deforested area, $A n$. darlingi occurred at all five larval habitats, while in Boa Vista, a savannah vegetation, this species was present in only two larval habitats and in lower numbers. The differences in the ecological environment between Boa Vista and São João da Baliza may account for this [38]. Studies have shown that $A n$. darlingi is often associated with low-lying vegetation along forested river margins and deforestation provides favourable conditions for this vector, thereby increasing malaria cases and decreasing scores of the Human Development Index [14, 45-48].

Anopheles darlingi has been found in a variety of larval habitats, both natural and man-made, and from large and permanent to small and temporary water bodies [13, 46-48]. In Boa Vista and São João da Baliza, An. darlingi were collected mainly in aquatic habitats with transparent water and moderate current with temperatures 
Table 4 Absolute number and relative frequency of adult anopheline species collected in the intradomicile, peridomicile and extradomicile by MosqTent (protected human baited) and Shannon trap (horse baited) from January 2017 to October 2018 in the municipalities of Boa Vista, Pacaraima and São João da Baliza

\begin{tabular}{|c|c|c|c|c|c|c|}
\hline \multirow[t]{4}{*}{ Municipalities } & \multirow[t]{4}{*}{ Species } & \multicolumn{4}{|c|}{ Sampling environments } & \multirow{4}{*}{$\begin{array}{l}\text { Total } \\
- \\
\mathrm{N}(\%)\end{array}$} \\
\hline & & \multirow{3}{*}{$\begin{array}{l}\text { Intradomicile } \\
N(\%)\end{array}$} & \multirow{3}{*}{$\begin{array}{l}\text { Peridomicile } \\
\mathrm{N}(\%)\end{array}$} & \multicolumn{2}{|c|}{ Extradomicile } & \\
\hline & & & & Mosquitent & Shannon & \\
\hline & & & & $N(\%)$ & $N(\%)$ & \\
\hline \multirow[t]{10}{*}{ Boa Vista } & An. darlingi & 0 & $20(27.4)$ & $42(57.5)$ & 11(15.1) & $73(6.9)$ \\
\hline & An. albitarsis s.l. & 0 & 190(20.4) & $669(71.9)$ & $71(7.6)$ & $930(88.4)$ \\
\hline & An. braziliensis & 0 & 0 & $8(100)$ & 0 & $8(0.8)$ \\
\hline & An.peryassui & 0 & $3(9.4)$ & $28(87.5)$ & $1(3.1)$ & $32(3.0)$ \\
\hline & An. nuneztovari s.l. & 0 & 0 & $3(60.0)$ & $2(40.0)$ & $5(0.5)$ \\
\hline & An. strodei & 0 & 0 & 0 & $1(100)$ & $1(0.1)$ \\
\hline & An. mattogrossensis & 0 & 0 & 0 & $1(100)$ & $1(0.1)$ \\
\hline & An. oswaldois.l. & 0 & $1(100)$ & 0 & 0 & $1(0.1)$ \\
\hline & An. evansae & 0 & 0 & $1(100)$ & 0 & $1(0.1)$ \\
\hline & Total & 0 & $214(20.3)$ & $751(71.4)$ & $87(8.3)$ & 1052 \\
\hline \multirow[t]{7}{*}{ Pacaraima } & An. darlingi & 0 & 0 & 0 & $1(100)$ & $1(1.0)$ \\
\hline & An. albitarsis s.l. & 0 & $2(25.0)$ & $1(12.5)$ & $5(62.5)$ & $8(8.3)$ \\
\hline & An. braziliensis & 0 & 21(33.8) & 18(29.0) & $23(37.1)$ & $62(64.6)$ \\
\hline & An. peryassui & 0 & $6(33.3)$ & $1(5.5)$ & $11(61.1)$ & $18(18.7)$ \\
\hline & An. nuneztovari s.l. & 0 & 0 & $1(100)$ & 0 & $1(1.04)$ \\
\hline & An. argyritarsis & 0 & $3(50.0)$ & $1(16.7)$ & $2(33.3)$ & $6(6.2)$ \\
\hline & Total & 0 & $32(33.3)$ & $22(22.9)$ & $42(43.8)$ & 96 \\
\hline \multirow[t]{8}{*}{ S.J. Baliza } & An. darlingi & $4(1.39)$ & 108(37.8) & 174(60.8) & 0 & $286(85.6)$ \\
\hline & An. albitarsis s.l. & 0 & $9(29.0)$ & $22(71.0)$ & 0 & $31(9.3)$ \\
\hline & An. nuneztovari s.l. & 0 & $3(23.1)$ & $9(69.2)$ & $1(7.7)$ & $13(3.9)$ \\
\hline & An. argyritarsis & 0 & $1(100)$ & 0 & 0 & $1(0.3)$ \\
\hline & An. strodei & 0 & 0 & $1(100)$ & 0 & $1(0.3)$ \\
\hline & An. oswaldois.l. & 0 & 0 & $1(100)$ & 0 & $1(0.3)$ \\
\hline & An. triannulatus s.l. & 0 & $1(100)$ & 0 & 0 & $1(0.3)$ \\
\hline & Total & $4(1.2)$ & $122(36.5)$ & $207(62.0)$ & $1(0.3)$ & 334 \\
\hline
\end{tabular}

between $22{ }^{\circ} \mathrm{C}$ and $28{ }^{\circ} \mathrm{C}$, in partially shaded areas with surrounding vegetation. According to Hiwat and Bretas [14], the immature stages of An. darlingi develop in aquatic habitats partial shaded, with temperature and $\mathrm{pH}$ varying, respectively, between 20 and $28{ }^{\circ} \mathrm{C}$, and 6.5 and 7 [14].

In Pacaraima, a mountainous region of an ombrophilous forest, An. darlingi larvae were not observed but one adult mosquito was collected. This species is not normally found in areas with high altitudes and in low temperatures [40]. However, recently it was collected at altitudes above $800 \mathrm{~m}$ in Venezuela, close to the border of Roraima [13]. Instead, An. triannulatus s.l. was the most abundant species collected in a single fishpond exposed to the sun that was located in a horticultural area and also in dams and streams in savannah and tropical forest larval habitats. Anopheles triannulatus s.l. seems to be a generalist as it demonstrated both widespread distribution and little if any environmental constraints [20, $49,50]$. This species appears to play an important role in malaria transmission in the states of Amapá, Amazonas, Pará and Peru [21, 23, 51, 52].

Anopheles albitarsis s.l., An. nuneztovari s.l., An. triannulatus s.l., An. oswaldoi s.l., and An. peryassui were found in all municipalities but in low numbers. In addition to the composition of anopheline larval species, a total of 1488 adult female Anopheles of 11 species were collected from all three municipalities. In São João da Baliza, where autochthonous malaria occurs, the most abundant species was An. darlingi (85.6\%), while in Boa Vista, the municipality with a high number of imported cases, An. albitarsis s.l. (88.4\%) was predominant, while An. braziliensis (64.6\%) was abundant in Pacaraima. Except for An. peryassui, all species collected have been 

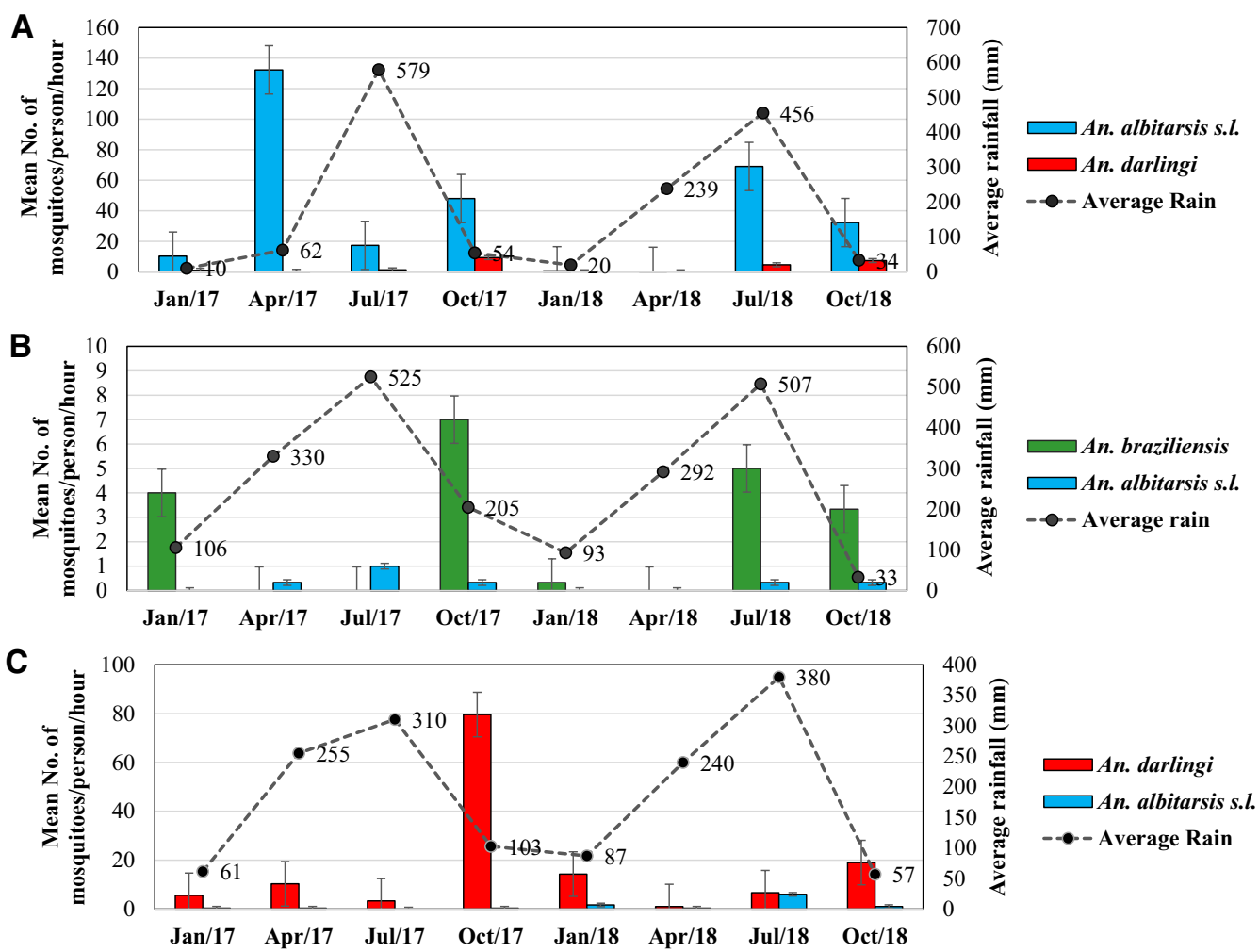

Fig. 3 Seasonal dynamics of the most abundant anopheline species in Boa Vista (A), Pacaraima (B) and São João da Baliza (C)

implicated as malaria vectors in the Brazilian Amazon $[21,53,54]$. Previous studies in Boa Vista corroborate this report regarding the composition of species found, with a greater abundance of An. albitarsis s.l. and a lower density of An. darlingi [24-26]. Anopheles albitarsis s.l. also had the highest HBR with 10.8 bites in the extradomicile and 3.8 in the peridomicile. However, in the $12-\mathrm{h}$ collection period it presented biting activity throughout the night, with the highest biting peak between 02:00 and 04:00, which differs from that previously reported [24-26]. Anopheles albitarsis s.l. has been assigned as an important vector in Para, Roraima, Amapá and Rondonia [23, 27, 54]. Because molecular analysis between members of An. albitarsis, An. nuneztovari, An. triannulatus, and An. oswaldoi complexes were not defined in this study, the presence of $A n$. janconnae or other species from this complex could not be confirmed in the studied municipalities. Presently, the only species of the An. albitarsis complex identified in the state of Roraima, has been An. janconnae, considered an important malaria vector in savannah habitat around Boa Vista [26]. Entomological surveillance to identify the component members of these complexes are mandatory to update the geographic distribution, ecological and biological aspects, and its possible role as a regional vector of malaria parasites in Roraima.

In Boa Vista, An. darlingi were collected in smaller numbers from 20:00 to 21:00 and 02:00 to 03:00, and its presence emerges with low HBR of 0.3 bites in the peridomicile, and 0.8 bites in the extradomicile. The presence of An. darlingi, even at low density in Boa Vista, can significantly contribute to transmission because it is highly anthropophilic and susceptible to Plasmodium parasites. Minimal biting indices could be sufficient to maintain the transmission cycle in Boa Vista [24, 51].

In São João da Baliza, An. darlingi was the most abundant species throughout the year, with a pronounced crepuscular biting activity in the peridomicile and extradomicile with early peak at 21:00-22:00 and throughout the night until early morning. Tadei et al. also found similar biting activity, whereas in Amapá this species showed a wide range of blood-feeding pattern [53-55]. In Venezuela, this mosquito bites throughout the night, with minor peaks at 23:00-00:00 and 03:00-04:00 [56]. The time of biting activity of anophelines depends on several factors, such as species density, seasonality and host availability $[53,57]$. 

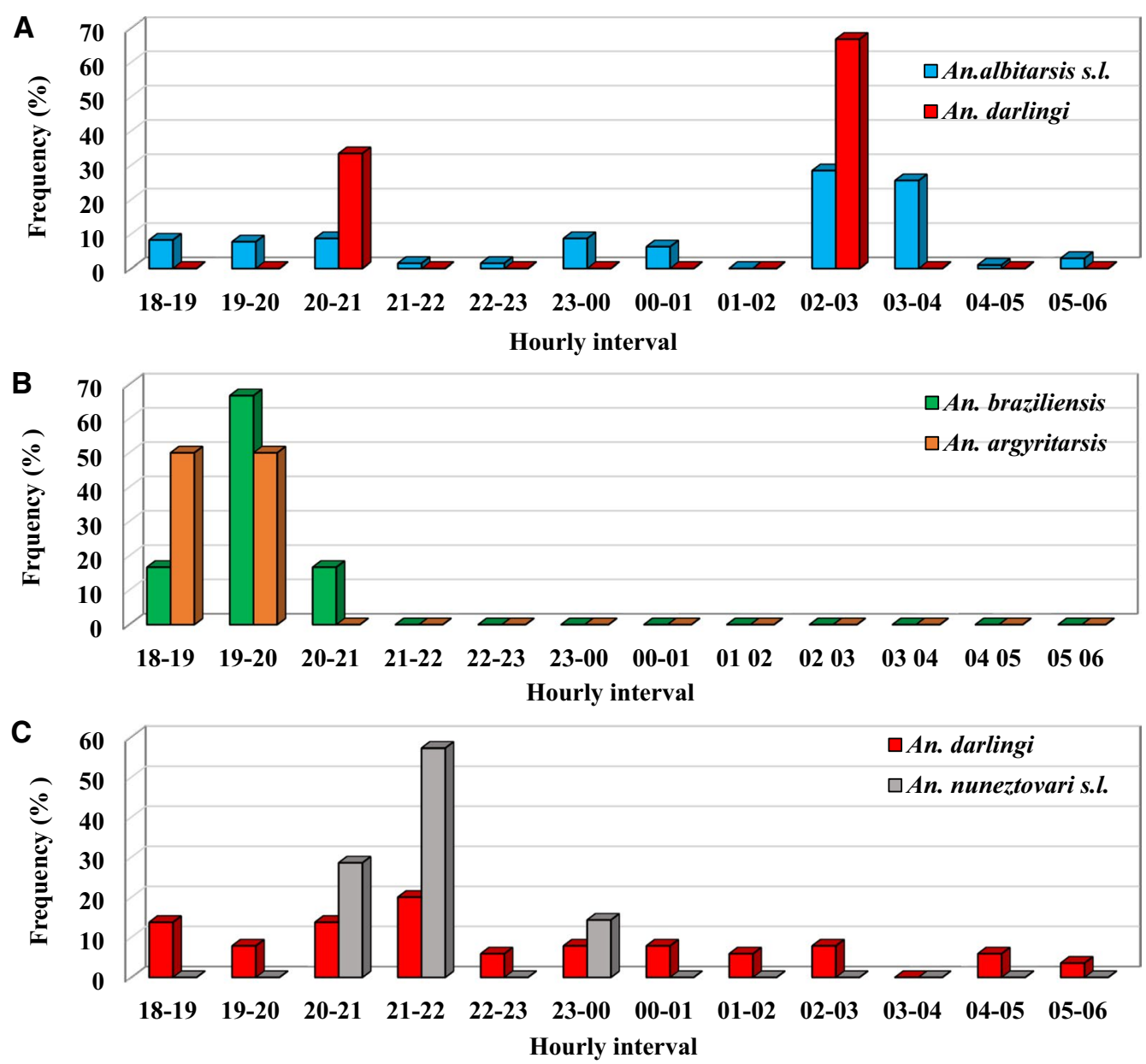

Fig. 4 Frequency by time of capture (from 12-h collections) of the main vectors collected in Boa Vista (A), Pacaraima (B) and São João da Baliza (C)

Table 5 Human biting rate per night by species in the peridomicile (PD) and extradomicile (ED) for each municipality

\begin{tabular}{lllc}
\hline Municipalities & Species & PD & ED \\
\hline Boa Vista & An. albitarsis s.l. & 3.8 & 10.8 \\
& An. darlingi & 0.3 & 0.8 \\
Pacaraima & An. braziliensis & 0.26 & 0.22 \\
& An. argyritarsis & 0.03 & 0.01 \\
São João da Baliza & An. darlingi & 1.07 & 1.64 \\
& An. albitarsis s.l. & 0.08 & 0.22 \\
\hline
\end{tabular}

Regarding seasonality, there was no significant correlation between abundance (of the species) and rainfall or the abundance of each species with locality or rainfall $(p>0.05)$. The lack of correlation between anopheline species and rainfall could be due to the variability in mosquito abundance among localities. In Boa Vista, the highest density of An. albitarsis s.l. occurred during the dry season but it was also collected in the period of high rainfall in 2018. Anopheles darlingi showed a peak after the rainy season (transition from rainy to dry season), in both years of collection, and a slightly lower peak in the middle of the rainy season, only in 2018. In Rondonia, genetic differences between the populations of $A n$. darlingi were characterized by microsatellites with distinct seasonal patterns [58], one of which, population A, presented the highest density at the end of the rainy season, and was characterized as a less abundant population in interior regions than in riparian areas. Another sub-population, population $B$, peaked at the beginning of the rainy season and was more abundant in the interior.

The HBR per night for An. darlingi was also considered high in this municipality with 1.64 bites in the extradomicile and 1.07 in the peridomicile. This likely contributes to transmission in this municipality. Heterogeneous biting behaviour of $A n$. darlingi in terms of blood feeding inside and outside houses and variations in the peak time 
of biting have been shown by numerous studies carried out across the Amazon and in Venezuela and French Guiana $[15,40,47,51,56,59,60]$. This behaviour is considered the main cause of the ineffectiveness of insecticide sprayed inside houses [61, 62]. One of the control measures used in the malaria control programme in Roraima is indoor residual spraying, which may explain the exophilic behaviour of this species in the studied area.

In addition to the presence of An. darlingi, An. nuneztovari s.l. and An. albitarsis s.l. were observed in the peridomicile and the extradomicile, but in low numbers compared to that of An. darlingi; An. nuneztovari s.l. was the second-most abundant species in São João da Baliza. This species is considered a primary malaria vector in Venezuela, Peru and Colombia [13, 63-65]. In Brazil, An. nuneztovari s.l. has been found naturally infected with $P$. vivax and $P$. falciparum in the Amazonian region and it has been incriminated as local vector in Amapá [21, 35, 53, 54]. However, most of Brazilian populations of $A n$. nuneztovari s.l. are predominantly zoophlilic and seem not to sustain malaria transmission in the absence of the primary vector $A n$. darlingi $[15,66]$. In the urban areas of Roraima, studies have shown a low population density and a low number of infectious An. nuneztovari s.l. [25].

The abundance of $A n$. darlingi throughout the year in São João da Baliza, along with their propensity to seek hosts throughout the night, and their ability to adapt host-seeking behaviour to local environments contributes to their impact as the most important vector in this municipality. In contrast in Pacaraima, since An. braziliensis was the predominant species, most adults were collected in the Shannon trap, where a horse was used for attraction. Anopheles braziliensis is present in most Amazonian states and is considered a secondary vector because it is primarily zoophilic and exophilic and are rarely involved in malaria transmission [25, 40]. Consoli and Lourenço-de-Oliveira [40], claimed that $A n$. braziliensis can be found biting during the day, especially when the host is relatively close to its larval habitat [40]. Importantly, it has been found to be infected with human malaria parasites in the states of Amazonas, Amapá, Rondônia and Roraima [15, 19, 54, 67]. Only one specimen of An. darlingi was collected in Pacaraima, but there is a report predicting the presence of this vector in indigenous areas in this municipality, where most of the autochthonous cases occur $[1,68]$. Taken together, $A n$. braziliensis may play some role in malaria transmission in Pacaraima when at high densities.

\section{Conclusion}

This study showed a diversity of anopheline larvae species and habitats in Boa Vista, Pacaraima and São João da Baliza. Anopheles darlingi appeared to be the most important vector in São João da Baliza, the area of autochthonous malaria, and An. albitarsis s.l. and An. braziliensis in areas of low transmission, although there are increasing reports of imported malaria. Considering the behaviour of the vectors in Boa Vista, Pacaraima and São João da Baliza, interventions such as intradomiciliary spraying will likely be insufficient to reduce malaria transmission. It can be speculated that the local vector assemblage in Boa Vista is sufficient to sustain the disease, and also provides a time buffer to mitigate the effects that imported cases would otherwise have if $A n$. darlingi were more prevalent. This circumstance offers an opportunity to reduce the effects of cross-border malaria via early diagnosis and timely treatment. In addition, environmental management of vector larval habitats and health education actions addressing individual and collective forms of prevention are indicated.

\section{Supplementary Information}

The online version contains supplementary material available at https://doi. org/10.1186/s12936-021-04033-1.

Additional file 1: Fig. S1. Dispersion graph of anopheline mosquitoes by mean intensity of rain, temperature and species.

\section{Acknowledgements}

We thank the technical team of the State Entomology Center for their support in the fieldwork and the mapping of larval habitats and the Secretary of Health of Roraima-General Coordination for Health Surveillance for fieldwork support. We also appreciate the reviewers for providing helpful comments and suggestions.

\section{Authors' contributions}

JOF, TFSN, and AAE conceived the idea and participated in the study design. TFSN, NCVA, MSASN, and JL were responsible for the sample collection. MSASN, JOF, NCVA, JL, TMC, and JS performed the experiments and analysed the data. NCVA drafted the manuscript, and JOF, TFSN and AAE performed revisions. All authors read, corrected and approved the final manuscript.

\section{Funding}

The study received financial support from PAEF (IOC-023-FIO-18-2-47 and Coordenação de Aperfeiçoamento de Pessoal de Nível Superior-Brasil

(CAPES)_Finance Code 001. JOF was the recipient of a Research Productivity Fellowship from the National Council of Scientific and Technological Development (CNPq). AAE was supported by a grant from the US National Institutes of Health, U19AI089681. The funders had no role in the study design, data collection and analysis, decision to publish, or manuscript preparation.

\section{Availability of data and materials}

The datasets during and/or analysed during the current study available from the corresponding author on reasonable request.

\section{Declarations}

Ethics approval and consent to participate Not applicable.

Consent for publication

Not applicable.

Competing interests

The authors declare that they have no competing interests. 


\section{Author details}

${ }^{1}$ Laboratório de Imunoparasitologia, Instituto Oswaldo Cruz, Fundação Oswaldo Cruz, Rio de Janeiro, Brasil. ${ }^{2}$ Universidade Federal de Roraima, Boa Vista, Roraima, Brasil. ${ }^{3}$ Laboratório de Mosquitos Transmissores de Hematozoários, Instituto Oswaldo Cruz, Fundação Oswaldo Cruz, Rio de Janeiro, Brasil. ${ }^{4}$ Instituto Nacional de Infectologia Evandro Chagas, Fundação Oswaldo Cruz, Rio de Janeiro, Brasil. ${ }^{5}$ Department of Biology/Institute for Genomics and Evolutionary Medicine (iGEM), Temple University, Philadelphia, PA, USA.

Received: 14 December 2021 Accepted: 18 December 2021

Published online: 14 January 2022

\section{References}

1. Ministério da Saúde, Brasil. Datasus. Sivep Malária. Sistema Eletrônico do Serviço de Informações ao Cidadão (e-SIC). 2021 [Available from: https:// esic.cgu.gov.br/sistema/site/index.aspx.Information

2. Arisco NJ, Peterka C, Castro MC. Cross-border malaria in Northern Brazil. Malar J. 2021:20:135.

3. Grillet ME, Moreno JE, Hernandez-Villena JV, Vincenti-Gonzalez MF, Noya O, Tami A, et al. Malaria in Southern Venezuela: the hottest hotspot in Latin America. PLoS Negl Trop Dis. 2021;15:e0008211.

4. Carlos BC, Rona LDP, Christophides GK, Souza-Neto JA. A comprehensive analysis of malaria transmission in Brazil. Pathog Glob Health. 2019;113:1-13.

5. Grillet ME, Hernandez-Villena JV, Llewellyn MS, Paniz-Mondolfi AE, Tami A, Vincenti-Gonzalez MF, et al. Venezuela's humanitarian crisis, resurgence of vector-borne diseases, and implications for spillover in the region. Lancet Infect Dis. 2019;19:e149-61.

6. Jaramillo-Ochoa R, Sippy R, Farrell DF, Cueva-Aponte C, Beltran-Ayala E, Gonzaga JL, et al. Effects of political instability in Venezuela on malaria resurgence at Ecuador-Peru border, 2018. Emerg Infect Dis. 2019;25:834-6.

7. Grillet ME, Villegas L, Oletta JF, Tami A, Conn JE. Malaria in Venezuela requires response. Science. 2018;359:528.

8. Louzada J, de Almeida NCV, de Araujo JLP, Silva J, Carvalho TM, Escalante $A A$, et al. The impact of imported malaria by gold miners in Roraima: characterizing the spatial dynamics of autochthonous and imported malaria in an urban region of Boa Vista. Mem Inst Oswaldo Cruz. 2020;115:e200043.

9. Vreden SG, Jitan JK, Bansie RD, Adhin MR. Evidence of an increased incidence of day 3 parasitaemia in Suriname: an indicator of the emerging resistance of Plasmodium falciparum to artemether. Mem Inst Oswaldo Cruz. 2013;108:968-73.

10. Chenet SM, Akinyi Okoth S, Huber CS, Chandrabose J, Lucchi NW,

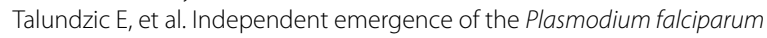
kelch propeller domain mutant allele C580Y in Guyana. J Infect Dis. 2016;213:1472-5.

11. Pacheco MA, Forero-Pena DA, Schneider KA, Chavero M, Gamardo A, Figuera L, et al. Malaria in Venezuela: changes in the complexity of infection reflects the increment in transmission intensity. Malar J. 2020;19:176.

12. Lucchi NW, Abdallah R, Louzada J, Udhayakumar V, Oliveira-Ferreira J. Molecular surveillance for polymorphisms associated with artemisininbased combination therapy resistance in Plasmodium falciparum isolates collected in the State of Roraima. Brazil Am J Trop Med Hyg. 2020:102:310-2

13. Sinka ME, Rubio-Palis Y, Manguin S, Patil AP, Temperley WH, Gething PW, et al. The dominant Anopheles vectors of human malaria in the Americas: occurrence data, distribution maps and bionomic precis. Parasit Vectors. 2010;3:72

14. Hiwat H, Bretas G. Ecology of Anopheles darlingi Root with respect to vector importance: a review. Parasit Vectors. 2011;4:177.

15. Tadei WP, Dutary TB. Malaria vectors in the Brazilian amazon: Anopheles of the subgenus Nyssorhynchus. Rev Inst Med Trop Sao Paulo. 2000;42:87-94.

16. Povoa MM, Conn JE, Schlichting CD, Amaral JC, Segura MN, Da Silva AN, et al. Malaria vectors, epidemiology, and the re-emergence of Anopheles darlingi in Belem, Para. Brazil J Med Entomol. 2003;40:379-86.
17. Moutinho PR, Gil LH, Cruz RB, Ribolla PE. Population dynamics, structure and behavior of Anopheles darlingi in a rural settlement in the Amazon rainforest of Acre. Brazil Malar J. 2011;10:174

18. Rufalco-Moutinho P, Schweigmann N, Bergamaschi DP, Mureb Sallum MA Larval habitats of Anopheles species in a rural settlement on the malaria frontier of southwest Amazon. Brazil Acta Trop. 2016;164:243-58.

19. Lourenco-de-Oliveira R, Guimaraes AE, Arle M, da Silva TF, Castro MG, Motta MA, et al. Anopheline species, some of their habits and relation to malaria in endemic areas of Rondonia State, Amazon region of Brazil. Mem Inst Oswaldo Cruz. 1989;84:501-14.

20. McKeon SN, Schlichting CD, Povoa MM, Conn JE. Ecological suitability and spatial distribution of five Anopheles species in Amazonian Brazil. Am J Trop Med Hyg. 2013;88:1079-86.

21. de Arruda M, Carvalho MB, Nussenzweig RS, Maracic M, Ferreira AW, Cochrane AH. Potential vectors of malaria and their different susceptibility to Plasmodium falciparum and Plasmodium vivax in northern Brazil identified by immunoassay. Am J Trop Med Hyg. 1986;35:873-81.

22. Barros FS, Honorio NA, Arruda ME. Mosquito anthropophily: implications on malaria transmission in the Northern Brazilian Amazon. Neotrop Entomol. 2010;39:1039-43.

23. de Oliveira-Ferreira J, Lourenco-de-Oliveira R, Teva A, Deane LM, DanielRibeiro CT. Natural malaria infections in anophelines in Rondonia State, Brazilian Amazon. Am J Trop Med Hyg. 1990;43:6-10.

24. de Barros FS, Honorio NA. Man biting rate seasonal variation of malaria vectors in Roraima. Brazil Mem Inst Oswaldo Cruz. 2007;102:299-302.

25. Silva-Vasconcelos A, Kato MY, Mourao EN, de Souza RT, Lacerda RN, Sibajev $A$, et al. Biting indices, host-seeking activity and natural infection rates of anopheline species in Boa Vista, Roraima, Brazil from 1996 to 1998. Mem Inst Oswaldo Cruz. 2002;97:151-61.

26. Povoa MM, de Souza RT, Lacerda RN, Rosa ES, Galiza D, de Souza JR, et al. The importance of Anopheles albitarsis $\mathrm{E}$ and An. darlingi in human malaria transmission in Boa Vista, state of Roraima, Brazil. Mem Inst Oswaldo Cruz. 2006;101:163-8.

27. Santos EA, Sucupira IMC, de Oliveira Martins BM, de Paula SEGRJ, Catete CP, de Souza RTL, et al. VK210 and VK247 genotypes of Plasmodium vivax in anopheline mosquitoes from Brazilian Amazon. Sci Rep. 2019;9:9391.

28. Motoki MT, Linton YM, Conn JE, Ruiz-Lopez F, Wilkerson RC. Phylogenetic network of mitochondrial $\mathrm{CO}$ gene sequences distinguishes 10 taxa within the neotropical Albitarsis Group (Diptera: Culicidae), confirming the separate species status of Anopheles albitarsis H (Diptera: Culicidae) and revealing a novel lineage Anopheles albitarsis J. J Med Entomol. 2021:58:599-607.

29. Brochero HH, Li C, Wilkerson RC. A newly recognized species in the Anopheles (Nyssorhynchus) albitarsis complex (Diptera: Culicidae) from Puerto Carreno. Colombia Am J Trop Med Hyg. 2007;76:1113-7.

30. Wilkerson RC, Foster PG, Li C, Sallum MA. Molecular phylogeny of neotropical Anopheles (Nyssorhynchus) Albitarsis species complex (Diptera: Culicidae). Ann Entomol Soc Am. 2005;98:918-25.

31. Gutierrez LA, Orrego LM, Gomez GF, Lopez A, Luckhart S, Conn JE, et al. A new mtDNA COI gene lineage closely related to Anopheles janconnae of the Albitarsis complex in the Caribbean region of Colombia. Mem Inst Oswaldo Cruz. 2010;105:1019-25.

32. Zuniga MA, Rubio-Palis Y, Brochero H. Updating the bionomy and geographical distribution of Anopheles (Nyssorhynchus) albitarsis F: a vector of malaria parasites in northern South America. PLoS One. 2021;16:e0253230.

33. Klein TA, Lima JB, Tada MS. Comparative susceptibility of anopheline mosquitoes to Plasmodium falciparum in Rondonia. Brazil Am J Trop Med Hyg. 1991;44:598-603.

34. Conn JE, Wilkerson RC, Segura MN, de Souza RT, Schlichting CD, Wirtz RA, et al. Emergence of a new neotropical malaria vector facilitated by human migration and changes in land use. Am J Trop Med Hyg. 2002;66:18-22.

35. Galardo AK, Arruda M, D'Almeida Couto AA, Wirtz R, Lounibos LP, Zimmerman $\mathrm{RH}$. Malaria vector incrimination in three rural riverine villages in the Brazilian Amazon. Am J Trop Med Hyg. 2007;76:461-9.

36. Moreno JE, Rubio-Palis Y, Paez E, Perez E, Sanchez V, Vaccari E. Malaria entomological inoculation rates in gold mining areas of Southern Venezuela. Mem Inst Oswaldo Cruz. 2009:104:764-8. 
37. Jiménez PCJ, Wirtz R, Brochero H. Anopheles (Diptera: Culicidae) vectores de malaria en el municipio de Puerto Carreño, Vichada. Colombia Biomédica. 2012;32:13-21.

38. Rosa-Freitas MG, Tsouris P, Peterson AT, Honorio NA, de Barros FS, de Aguiar DB, et al. An ecoregional classification for the state of Roraima, Brazil: the importance of landscape in malaria biology. Mem Inst Oswaldo Cruz. 2007:102:349-57.

39. Barni PE, Manzi AO, Condé TM, Barbosa RI, Fearnside PM. Spatial distribution of forest biomass in Brazil's state of Roraima, northern Amazonia. Forest Ecol Manag. 2016;377:170-81.

40. Consoli RAGB, Lourenço-de-Oliveira R. Principais mosquitos de importância sanitária no Brasil. Rio de Janeiro, Brazil: Fiocruz; 1994.

41. Nasci RS. A lightweight battery-powered aspirator for collecting resting mosquitoes in the field. Mosq News. 1981;41:808-11.

42. Lima JB, Galardo AK, Bastos LS, Lima AW, Rosa-Freitas MG. MosqTent: An individual portable protective double-chamber mosquito trap for anthropophilic mosquitoes. PLoS Negl Trop Dis. 2017;11:e0005245.

43. Nasir SMI, Amarasekara S, Wickremasinghe R, Fernando D, Udagama P. Prevention of re-establishment of malaria: historical perspective and future prospects. Malar J. 2020;19:452.

44. Sanchez-Ribas J, Oliveira-Ferreira J, Gimnig JE, Pereira-Ribeiro C, SantosNeves MSA, Silva-do-Nascimento TF. Environmental variables associated with anopheline larvae distribution and abundance in Yanomami villages within unaltered areas of the Brazilian Amazon. Parasit Vectors. 2017;10:571.

45. Rubio-Palis Y, Bevilacqua M, Medina DA, Moreno JE, Cardenas L, Sanchez $V$, et al. Malaria entomological risk factors in relation to land cover in the Lower Caura River Basin. Venezuela Mem Inst Oswaldo Cruz. 2013;108:220-8.

46. Barros FS, Arruda ME, Gurgel HC, Honorio NA. Spatial clustering and longitudinal variation of Anopheles darlingi (Diptera: Culicidae) larvae in a river of the Amazon: the importance of the forest fringe and of obstructions to flow in frontier malaria. Bull Entomol Res. 2011;101:643-58.

47. Charlwood JD. Biological variation in Anopheles darlingi Root. Mem Inst Oswaldo Cruz. 1996;91:391-8.

48. Hiwat H, Issaly J, Gaborit P, Somai A, Samjhawan A, Sardjoe P, et al. Behavioral heterogeneity of Anopheles darlingi (Diptera: Culicidae) and malaria transmission dynamics along the Maroni River, Suriname, French Guiana. Trans R Soc Trop Med Hyg. 2010;104:207-13.

49. Ramirez PG, Stein M, Etchepare EG, Almiron WR. Diversity of anopheline mosquitoes (Diptera: Culicidae) and classification based on the characteristics of the habitats where they were collected in Puerto Iguazu, Misiones. Argentina J Vector Ecol. 2016;41:215-23.

50. Moreno JE, Rubio-Palis Y, Sanchez V, Martínez Á. Population fluctuation and larval habitat of anopheline in the Municipality of Sifontes, Bolivar State. Venezuela Bol Mal Salud Amb. 2015:55:52-68.

51. Deane LM. Malaria vectors in Brazil. Mem Inst Oswaldo Cruz. 1986;81:5-14.

52. Hayes J, Calderon G, Falcon R, Zambrano V. Newly incriminated anopheline vectors of human malaria parasites in Junin Department. Peru J Am Mosq Control Assoc. 1987;3:418-22.

53. Tadei WP, Thatcher BD, Santos JM, Scarpassa VM, Rodrigues IB, Rafael MS Ecologic observations on anopheline vectors of malaria in the Brazilian Amazon. Am J Trop Med Hyg. 1998;59:325-35.

54. Povoa M, Wirtz R, Lacerda R, Miles M, Warhurst D. Malaria vectors in the municipality of Serra do Navio, State of Amapa, Amazon Region. Brazil Mem Inst Oswaldo Cruz. 2001:96:179-84.

55. Voorham J. Intra-population plasticity of Anopheles darlingi's (Diptera, Culicidae) biting activity patterns in the state of Amapa. Brazil Rev Saude Publica. 2002;36:75-80.

56. Moreno JE, Rubio-Palis Y, Paez E, Perez E, Sanchez V. Abundance, biting behaviour and parous rate of anopheline mosquito species in relation to malaria incidence in gold-mining areas of southern Venezuela. Med Vet Entomol. 2007:21:339-49.

57. de Barros FS, Arruda ME, Vasconcelos SD, Luitgards-Moura JF, Confalonieri U, Rosa-Freitas MG, et al. Parity and age composition for Anopheles darlingi root (Diptera: Culicidae) and Anopheles albitarsis Lynch-Arribalzaga (Diptera: Culicidae) of the northern Amazon Basin. Brazil J Vector Ecol. 2007;32:54-68
58. Angella AF, Salgueiro P, Gil LH, Vicente JL, Pinto J, Ribolla PE. Seasonal genetic partitioning in the neotropical malaria vector Anopheles darlingi. Malar J. 2014;13:203.

59. Forattini OP. Exophilic behavior of Anopheles darlingi Root in a southern region of Brazil. Rev Saude Publica. 1987;21:291-304.

60. Vezenegho SB, Adde A, Pommier de Santi V, Issaly J, Carinci R, Gaborit $P$, et al. High malaria transmission in a forested malaria focus in French Guiana: how can exophagic Anopheles darlingi thwart vector control and prevention measures? Mem Inst Oswaldo Cruz. 2016;111:561-9.

61. Prussing C, Moreno M, Saavedra MP, Bickersmith SA, Gamboa D, Alava F, et al. Decreasing proportion of Anopheles darlingi biting outdoors between long-lasting insecticidal net distributions in peri-lquitos. Amazonian Peru Malar J. 2018;17:86.

62. Prado CC, Alvarado-Cabrera LA, Camargo-Ayala PA, Garzon-Ospina D, Camargo M, Soto-De Leon SC, et al. Behavior and abundance of Anopheles darlingi in communities living in the Colombian Amazon riverside. PLoS One. 2019;14:e0213335.

63. Rubio-Palis Y, Wirtz RA, Curtis CF. Malaria entomological inoculation rates in western Venezuela. Acta Trop. 1992;52:167-74.

64. Naranjo-Diaz N, Altamiranda-Saavedra M, Correa MM. Anopheles species composition and entomological parameters in malaria endemic localities of North West Colombia. Acta Trop. 2019;190:13-21.

65. Fajardo P, Alzate A. Anopheles nuñeztovari como vector de malaria en el Bajo Calima. Buenaventura Col Med. 1987;18:14-8.

66. Marrelli MT, Floeter-Winter LM, Malafronte RS, Tadei WP, Lourenco-deOliveira R, Flores-Mendoza C, et al. Amazonian malaria vector anopheline relationships interpreted from ITS2 rDNA sequences. Med Vet Entomol. 2005;19:208-18.

67. Martins-Campos KM, Pinheiro WD, Vitor-Silva S, Siqueira AM, Melo GC, Rodrigues IC, et al. Integrated vector management targeting Anopheles darlingi populations decreases malaria incidence in an unstable transmission area, in the rural Brazilian Amazon. Malar J. 2012;11:351.

68. de Barros FS, de Aguiar DB, Rosa-Freitas MG, Luitgards-Moura JF, Gurgel $\mathrm{HC}$, Honorio NA, et al. Distribution summaries of malaria vectors in the northern Brazilian Amazon. J Vector Ecol. 2007;32:161-7.

\section{Publisher's Note}

Springer Nature remains neutral with regard to jurisdictional claims in published maps and institutional affiliations.

Ready to submit your research? Choose BMC and benefit from

- fast, convenient online submission

- thorough peer review by experienced researchers in your field

- rapid publication on acceptance

- support for research data, including large and complex data types

- gold Open Access which fosters wider collaboration and increased citations

- maximum visibility for your research: over 100M website views per year

At BMC, research is always in progress.

Learn more biomedcentral.com/submissions 